\title{
Development of Interactive Multimedia-Based Science Teaching Materials
}

\author{
Lala Jelita Ananda ${ }^{1 *}$, Fahurrozi $^{2}$, Lidia Simanihuruk ${ }^{3}$ \\ Elementary School Teacher Education, Universitas Negeri Medan, Indonesia \\ *ljananda.84@gmail.com
}

\begin{abstract}
The general objective of this study was to obtain a valid and practical Interactive multimedia-based science teaching materials for Unimed Elementary School Teacher Education students. Development of interactive multimedia-based science teaching materials is carried out using the four D (4-D) model. However, in this study only 3 stages were carried out, defining, designing, and developing. The dissemination phase was not carried out because of limited costs and time. The test subjects in this study were Elementary school teachers student Medan State University. Research variables included material validity, multimedia validity, and student interest. Data analysis techniques that will be performed are data validity analysis, practicality data analysis, effectiveness test data analysis. Values obtained from the validation results of interactive multimedia teaching materials are valid categories. Student interest in participating in learning using interactive multimedia teaching materials The Basic Concepts of Natural Sciences are included in the high category so that these teaching materials are practical for use in learning.
\end{abstract}

Keywords : interactive multimedia, science teaching materials.

\section{Introduction}

Nowadays technology is developing so fast. Along with this education is also required to balance the development of Information and Communication Technology (ICT), especially in the teaching and learning process. One of the applications of ICT in the learning process is the use of interactive multimedia teaching materials. ICTs help the learning process to be more effective and more meaningful [1].

Since the enactment of the KKNI Curriculum (Indonesian National Qualification Framework) at Unimed in 2016, Unimed has also increasingly promoted Blended Learning. Where in Mixed Learning allows students to learn (at least in part) through content and instructions delivered online (in a network) with independent control over the time, place, sequence, and speed of learning. To carry out Mixed Learning through this online, it is very much needed multimedia teaching materials that are teaching materials that can be uploaded to e-learning pages (online) so that students can easily learn learning materials through these pages.

Based on the explanation above, it is felt very necessary to develop interactive multimedia teaching materials that can be used in Natural Science Basic Concepts courses as well as to improve mastery of Basic Science concept materials for Unimed Elementary School Teacher Education students. 
The importance of the use of interactive multimedia teaching materials in science basic concepts courses is a must given the Mixed Learning system that has been implemented at Unimed, so that in learning it requires teaching materials that must be adapted to learning materials. Interactive multimedia teaching materials in the Science Basic Concepts course are expected to play a role in helping students master the Basic Science Concepts, as well as to make it easier for students to do online learning.

The main focus of this research is to develop interactive multimedia teaching materials in the Natural Science Basic Concepts using Computer Multimedia-based Technology as an alternative problem solving in improving the mastery of Basic Science Concepts materials at Unimed Elementary School Teacher Education students as well as supporting the process of mixed learning (Blended Learning).

The general objective of this research is to create interactive multimedia teaching materials in the Science Basic Concept courses for Unimed Elementary School Teacher Education students.

\section{Research Method}

This research was conducted at the Faculty of Education Unimed Elementary School Teacher Education students on first semester in 2019/2020. This research begins with the preparation of research, making proposals and designing research, conducting research, processing data, discussing research results and reporting. When the research was carried out for 7 months, starting from June to December 2019.

This study uses 4D models (four-D models). The development of the four-D model consists of 4 main stages, namely: 1) define (determine), 2) design, 3) develop, and 4) dessiminate (deployment) [2]. In this study only carried out until the develop stage only, the desseminate stage was not carried out.

The development of science teaching materials based on interactive multimedia is carried out using the four D (4-D) model. However, in this study only 3 stages were carried out, defining, designing, and developing. The dissemination phase was not carried out because of limited costs and time.

The procedure of making these science teaching materials is based on the following:

(1) Defining Phase (define), this stage aims to determine the objectives of the courses in the curriculum. At this stage there are three steps in the activity, namely curriculum analysis, analysis of student analysis concepts.

a. Curriculum analysis is analyzing learning outcomes based on KKNI.

b. Concept analysis is conducted to find out the main concepts that must be mastered by students, namely the Basic Concept of Natural Sciences material.

c. Student analysis is carried out to determine student characteristics including age, motivation, different background knowledge and education, academic abilities, and social skills;

(2) Design Phase (design), this stage aims to design science teaching materials based on Interactive Multimedia. Based on the analysis of the concepts that have been carried out in the Defining Stage and then designed a Teaching Material for Basic Concepts of Science based on Interactive Multimedia. This teaching material is created using the Adobe Flash application. This teaching material 
will contain materials for the Basic Concept of Science and pictures or illustrations related to these materials.

(3) Development Phase (develop), this stage aims to produce subjects for science subjects on basic concepts of interactive multimedia-based Science that are valid, practical, and effective. This development phase includes validity, practicality, and effectiveness. Validity means that the teaching materials that are designed will be validated by experts according to their field of expertise. Meanwhile, practicality means that after the validity testing phase is revised, it will then be tested during lectures to find out the practicality. Practicality is the level of practicality of Teaching Materials when used in the learning process, while effectiveness is an assessment of the effectiveness aspects of the Subject Teaching Material Basic Concepts of Interactive Multimedia-Based Science in the form of cognitive evaluation results that are the results of student learning tests and student activities during the learning process.

The research design can be seen in the following fishbone diagram :

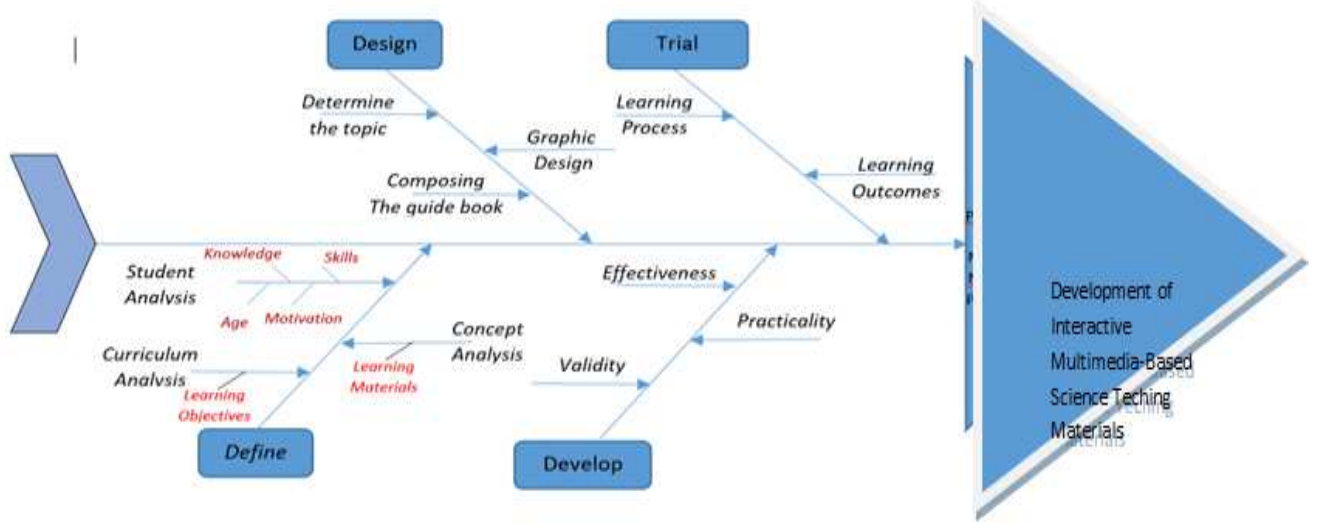

Fig 1. Research design

\section{Data Analysis Techniques}

Data Validity Analysis

To analyze the validity of instructional materials used a Likert scale based on the validation sheet with the steps:

a. Score each item with a very good answer (5), good (4), enough (3), less (2), bad (1);

b. Add up the total score for each validator for all indicators;

c. Providing validator values.

For data validity analysis using formulas :

$$
\text { validitas }=\frac{\text { skor yang diperoleh }}{\text { skor maximum }} \times 100 \%
$$


Table 1. The level of achievement of the validity category of teaching materials

\begin{tabular}{lcc}
\hline No & $\begin{array}{c}\text { Degree of achievement }(\%) \\
(\%)\end{array}$ & Category \\
\hline 1 & $90-100$ & very valid \\
2 & $80-89$ & valid \\
3 & $65-79$ & quite valid \\
4 & $55-64$ & less valid \\
5 & $0-54$ & very less \\
\hline
\end{tabular}

Information: Teaching Material is said to be valid if it has reached a validity level above $80 \%$.

\section{A. Practicality data analysis}

Practicality data analysis to analyze the practicality of teaching materials is based on a questionnaire given to students. The questionnaire was arranged on a Likert scale with a positive category. By using a formula that was modified from:

$$
\text { output level }=\frac{\sum X}{n \times \sum \text { item } x \text { scale } \max } \times 100
$$

$$
\text { Doutput level }=\frac{\sum \text { item }}{\sum \text { score } \max } \times 100 \% \text { modified }
$$

Table 2 Level of practicality of teaching materials

\begin{tabular}{ccc}
\hline No & Degree of achievement (\%) & Category \\
\hline 1 & $90-100$ & Very practical \\
2 & $80-89$ & practical \\
3 & $65-79$ & quite practical \\
4 & $55-64$ & less practical \\
5 & $0-54$ & very impractial \\
\hline
\end{tabular}

Information : Teaching Material is said to be practical if it has reached a practical level above $80 \%$.

\section{Analysis of effectiveness test data}

Effectiveness is observed from the analysis of student learning outcomes, namely cognitive learning outcomes. Determining student completeness can be calculated using the following equation; 


$$
K B=\frac{T}{T t} x 100 \%
$$

Information $: \mathrm{KB}=$ Mastery learning, $\mathrm{T}=$ Number of scores obtained, $\mathrm{Tt}=$ Number of scores obtained.

Each student is said to have finished learning if the proportion of correct answers is $\geq 65 \%$ and a class is said to have finished learning if in class there are $\geq 85 \%$ of students completed [3]. Teaching Materials are said to be effective if student learning outcomes have met the aata about student activities towards learning activities were analyzed using percentages (\%). Standards that if $\geq 85 \%$ of students have been completed.

$$
P=\frac{F}{N} x 100 \%
$$

Information : $\mathrm{P}=$ Percentage of student activity, $\mathrm{F}=$ Frequency of active students, $\mathrm{N}=$ Total number of students

The percentage of student activity data obtained is grouped according to the following criteria: $81 \%-100 \%=$ very active, $61 \%-80 \%=$ active, $41 \%-60 \%=$ moderately active, $21 \%$ - $40 \%=$ less active, $0 \%-20 \%=$ very less active. Learning Media is said to be effective if students meet the criteria $41 \%-100 \%$.

\section{Results and Discussion}

In this research, the development of science teaching materials based on interactive multimedia using the Macromedia Flash Player 8 application. This research development uses 4D (four-D models) consisting of 4 main stages, namely: 1) define, 2) design, 3) develop, and 4) dessiminate. In this study only carried out until the develop stage only, the desseminate stage was not carried out. The process of making these Science teaching material based on Interactive Multimedia is as follows:

1) Defining Stage.

At this stage an analysis of learning objectives and teaching materials is carried out in the Science Concept Basic course. The analysis was conducted based on the need to master the science concepts at the level of undergraduate students at the PGSD study program. From the results of this analysis 9 (nine) main subjects were obtained in the basic science concept courses with each different learning objective.

2) Design Stage.

At this stage the design of teaching materials for interactive multimedia Science Concepts is based on interactive multimedia. The design of teaching materials is arranged using the Macromedia Flash Player 8 application. These teaching materials are composed of menu buttons with different functions. The menu buttons include learning material, learning objectives, videos, pictures and questions. The following are design drawings from the teaching materials of the Basic Concepts of Science based on interactive multimedia. 

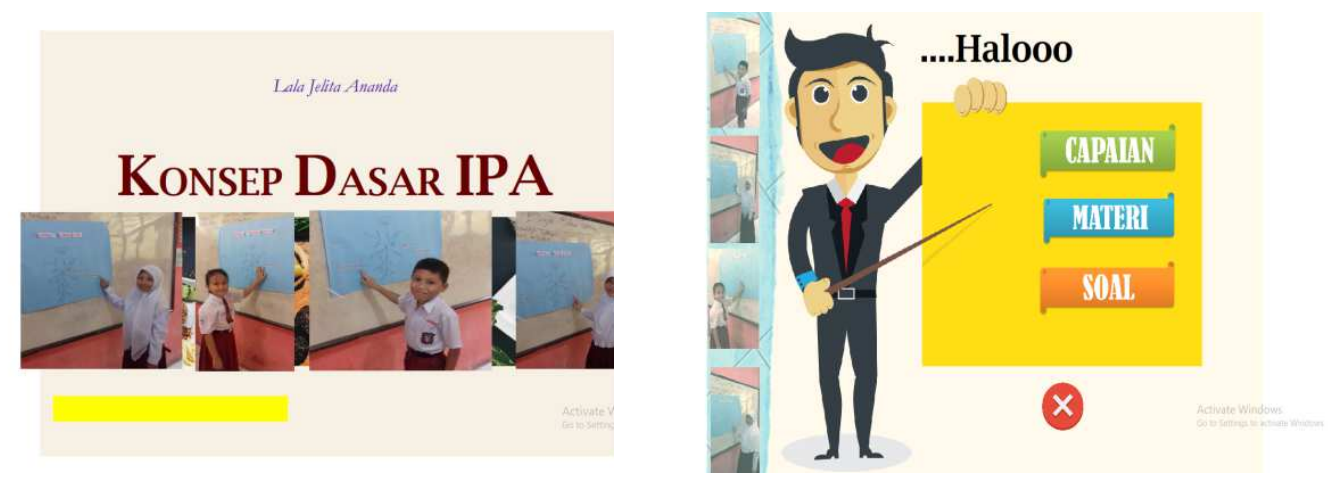

Fig 2. Initial display and interactive multimedia teaching material menu
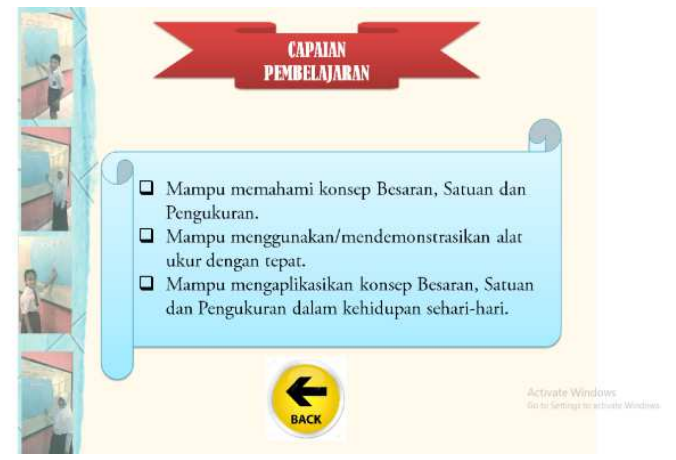

Fig 3. Display learning outcomes and questions

3) Development Stage

This development phase includes validity, practicality, and effectiveness. After the initial product development is carried out, the next step is validation, which is an assessment of multimedia teaching materials for the Science Material Teaching. This validation carried out by multimedia design experts and material experts. Validation done by filling out a questionnaire.

In the first stage of multimedia validation, it obtained an average score of 3.81 which was included in both categories. Some of the material and images contained in interactive multimedia Science teaching materials must be reduced and replaced because they are considered less effective and less communicative so that the material is reduced and for images to be replaced into more communicative images. Assessment of the second stage multimedia expert obtained a score of 4.38 in the excellent category.

After the validation of multimedia experts and material experts the next stage was tested on multimedia teaching materials for Basic Concepts of Natural Sciences. The initial field trial was carried out involving 5 Unimed elementary school teacher education students. The first trial results obtained an average score of 4.65 and included in the excellent category. After the 
repairs are done, then a second trial is conducted. The second trial was a field trial involving 35 Unimed elementary school teacher education students. The field trial results obtained a score of 4.80 and included in the excellent category.

Based on the main field trials, it was obtained that the student's assessment of interactive multimedia teaching materials on the Basic Concept of Natural Sciences had shown the category of "Very Good". In implementing learning, researchers do not find the problem means it. So that it can be stated in this field trials, multimedia teaching materials The Basic Concept of Science does not require revision and can be used in learning.

\section{Conclusion}

Development of Science teaching materials interactive multimedia based using Macromedia Flash Player 8 applications. This research development uses 4D (four-D models) consisting of 4 main stages, namely: 1) define (determine the material), 2) design, 3) develop, and 4) dessiminate. In this study only carried out until the develop stage only, the desseminate stage was not carried out. This development phase includes validity, practicality, and effectiveness. After the initial product development is carried out, the next step is validation, which is an assessment of Science multimedia teaching materials. This validation carried out by multimedia design experts and material experts. Validation done by filling out a questionnaire. In the first stage of multimedia validation, it obtained an average score of 3.81 that was included in both categories. Assessment of the second stage multimedia expert obtained a score of 4.38 in the excellent category. The first trial results obtained an average score of 4.65 and included in the excellent category. The field trial results obtained a score of 4.80 and included in the excellent category. Based on the main field trials, it was obtained that the student's assessment of interactive multimedia teaching materials on the Basic Concept of Natural Sciences had shown the category of "Very Good". So that it can be stated in field trials this, multimedia teaching materials The Basic Concept of Science does not require revision and can be used in learning

\section{References}

[1] Jupriyanto dan Turahmat. Pengembangan Bahan Ajar Multimedia Interaktif Dalam Pembelajaran IPA Kelas V. UIN Sultan Agung: Jurnal Pendidikan Guru Sekolah Dasar. Vol. 1 (2017).

[2] Prasetyo, Sigit. Pengembangan Media Pembelajaran IPA Berbasis Android untuk Siswa SD/MI. Jurnal of Madrasah Ibtidaiyah Education (JMIE) Vol.I No.1. Yogyakarta: Universitas Islam Negeri Sunan Kalijaga (2017).

[3] Atun, Ria Syafa. Pengembangan Media Kartun IPA Pokok Bahasan Gaya Magnet Kelas V di SD Negeri Sekarsuli. Universitas Negeri Yogyakarta: Jurnal Pendidikan Guru Sekolah Dasar (2016).

[4] Irfan, Muh. Pengembangan Multimedia Interaktif Untuk Pembelajaran Matakuliah Konsep Dasar IPA 1. Jurnal Publikasi pendidikan Vol.II No.1 (2012).

[5] Anggoro, Subuh dan Badarudin. Meningkatkan Pemahaman Mahasiswa pada Matakuliah Konsep Dasar IPA Menggunakan Model Pembelajaran CBSA dengan Pendekatan Discovery. Purwokerto: Universitas Muhammadiyah (2010). 